\title{
МАТЕРІАЛИ ДЛЯ РЕКОНСТРУКЦІЇ ТРАВМОВАНОЇ ПЕРЕДНЬОЇ ХРЕСТОПОДІБНОЇ ЗВ'ЯЗКИ У СПОРТСМЕНІВ
}

\author{
Лисичина С. В., студентка \\ redred1916@gmail.com \\ Беспалова О.Я., доц., к.б.н., с.н.с. \\ bespalova25.05@gmail.com \\ Кафедра БМІ, ФБМІ \\ Національний технічний університет України \\ «Київський політехнічний інститут імені Ігоря Сікорського» \\ Київ, Україна
}

\begin{abstract}
Реферат - У силу різних причин та особливостей в сучасному професійному спорті невпинно збільиуються кількість та важкість травм. Особливо важливими та небезпечними є пошкодження нижньої кіниівки, серед яких не останнє місие займають розриви передньої хрестоподібної зв'язки, однієї з найбільш травмованих зв'язок колінного суглобу.

Особливість травм ПХЗ у спортсменів полягає в тому, щзо вони після операцій повинні в максимально короткий термін повернутися до попередніх тренувань і витримувати систематичні навантаження.

Класична реконструкція передньої хрестоподібної зв'язки з використанням власних тканин пацієнта та оперативним лікуванням супутніх ушкоджень не дає можливості швидко повернутися в професійний спорт, оскільки вимагає тривалої релаксацї та спокою до моменту повного загоєння рани.

Завдяки розвитку біомедичних технологій, одним з методів лікування розриву ПХЗ стала мало інвазивна артроскопічна техніка, яка забезпечує нижчу травматичність втручання та пришвидиує процес реабілітації в такий спосіб. Але попри безліч сучасних матеріалів і типів протезів для ПХЗ, має місие високий відсоток незадовільних функціональних результатів, ранніх та віддалених післяопераційних ускладнень, пов'язаних з імплантацією в суглоб синтетичних тканин.

У роботі було проведено порівняльний аналіз методик реконструкиії травмованої передньої хрестоподібної зв'язки, визначення недоліків в техніках та імплантатах, які застосовуються наразі, формування основних вимог для їх вдосконалення та розробка пропозичій особливих вимог для лікування спортсменів з травмами ПХЗ.

У середовищі «SolidWorks» були умовно змодельовані 2 зразки імплантатів зв'язки, математичний аналіз та порівняння синтетичного імплантата та ауто трансплантата демонструє, щьо синтетична ПХЗ витримує навантаження до 387 Н, в той час як зв'язка з тканин людини - лише $203 \mathrm{H}$.

3 огляду на всі вище вказані дані, на даному етапі розвитку медичних технологій сучасним лікарям-травматологам варто більш часто розглядати реконструкцію ПХЗ методом мало інвазивної артроскопї з використанням синтетичних імплантатів. Тому що відповідно до отриманих результатів саме такий підхід до лікування може сприяти скороченню часу реабілітації у спортсменів та допоможе їм в мінімальні терміни повернутись до занять.

Ключові слова - травми колінного суглобу, травма передньої хрестоподібної зв'язки, ауто трансплантат, синтетичний імплант, політетрафторетилен.
\end{abstract}

\section{I. ВСТУП}

Травми, пов'язані з спортом, попри зростання кількості більш безпечного устаткування, продовжують зростати і за різними джерелами займають близько 2-5 \% від загального травматизму. 3 кожним роком у світі професійного спорту ставляться нові рекорди та підвищуються вимоги. Відповідно наступним поколінням спортсменів стає все важче i довше досягнути планки попередніх і доводиться докладати все більше зусиль для отримання бажаного результату [1,2]. А внаслідок збільшення кількості тренувань та ускладнення нормативів щороку збільшується і кількість травм.

У 2007 Національна Університетська Спортивна Асоціація (NCAA) представила дані про 182000 пошкоджень за 16-річний період часу (з 1988/1989 по 2003/2004)з 15 видів спорту, більше 50\% усіх пошкоджень були пов'язані з травмами нижньої кінцівки, а особливо коліном і щиколоткою [3].

Травми передньої хрестоподібної зв'язки (ПХЗ) найчастіше зустрічається серед людей, котрі активно займаються спортом. Передня хрестоподібна зв'язка 
знаходиться в самому центрі колінного суглоба, починається від внутрішньої кістки, проходячи через міжщілинкову вирізку, прямує вниз, вперед і всередину, прикріплюючись до переднього міжщілинкового поля великогомілкової кістки. Передня хрестоподібна зв'язка стабілізує колінний суглоб і не дає гомілці надмірно зміщуватися вперед, а також утримує зовнішню міжущілину великогомілкової кістки. Крім того, що передня хрестоподібна зв'язка колінного суглобу виконує стабілізаційну функцію (утримує гомілку від зсуву вперед і всередину), в ній є ще й нервові закінчення, які сигналізують про те, в якому положенні (зігнутому або розігнутому) знаходиться колінний суглоб [4].

Більшість розтягувань i розривів передньої хрестоподібної зв'язки відбуваються через травму, як правило, в спорті чи фітнесі. Зв'язка розтягується або розривається, коли при зафіксованій стопі i гомілці коліно блокується і крутиться або повертається одночасно, так зване скручування в коліні $[5,6]$.Травма передньої хрестоподібної зв'язки призводить до руйнування інших структур колінного суглоба, і розвитку артрозу.

Оскільки ПХЗ - одна 3 найбільш травмованих зв'язок колінного суглобу i особливість травм ПХЗ у спортсменів полягає ще й тому в тому, що вони після операцій повинні в максимально короткий термін повернутися до попередніх тренувань i витримувати систематичні навантаження. Тому в ході вибору імплантата, лікування та реабілітації потрібен більш серйозний i ретельний підхід, що зможе забезпечити надійний результат.

\section{ІІ. ОГЛЯД ЛІТЕРАТУРИ}

\section{Особливості травми ПХЗ.}

Реконструкція передньої хрестоподібної зв'язки залишається однією 3 найбільш загально прийнятих операцій, які виконують травматологи-ортопеди. Пластику ПХ3 виконують як відкритим способом, так і за допомогою сучасних методик шляхом ендоскопічної апаратури 3 використанням різноманітних трансплантатів та технік фіксацї.
Вибір типу операції залежить від декількох факторів, у тому числі - степеня пошкодження самої зв'язки та рівня спортивної активності пацієнта.

Зважаючи на тип отриманої травми ПХЗ в сучасних медичних технологіях використовуються декілька різних видів реконструкції пошкодженої ділянки [7].

Основним методом, що переважно застосовуються в сучасній медичній практиці, зокрема ті, які використовуються в відділенні спортивної та балетної травми Інституту травматології та ортопедії НАМН, є класична реконструкція передньої хрестоподібної зв'язки 3 використанням власних тканин пацієнта (зв'язки надколінка або зв'язок на пів сухожильних м'язів) 3 оперативним лікуванням супутніх ушкоджень [8].

3 аналізу вивчених історій пацієнтів відділення спортивної та балетної травми видно, що близько 30 \% пацієнтів, до яких застосовувались класичні методи лікування, мали повторні травми, біль, набряк i нестабільність періодично виникають у 5689\% спортсменів 3 розривами передньої хрестоподібної. Консервативне лікування травм передньої хрестоподібної зв'язки зазвичай не дає хороших і дійсно надійних результатів у людей, які повертаються до інтенсивних спортивних занять, адже вони несуть постійні навантаження на травмовані ділянки коліна, викликають розслаблення зв'язки і їі вихід з ладу.

Сучасні методики лікуванння травм ПХЗ З. За останні декілька десятиліть було розроблено багато альтернативних методик, які пришвидшують процес реабілітації та зменшують ризик повторного травмування ПХЗ. Зокрема для реконструкції ПХЗ почали використовувати не лише аутотрансплантати, а й штучні імпланти, фіксатори та алло матеріали [9].

Завдяки розвитку біомедичних технологій, одним 3 методів лікування розриву ПХ3 $є$ мало інвазивна артроскопічна техніка, яка забезпечує нижчу травматичність втручання та пришвидшує процес реабілітації в такий спосіб [10].

При цьому питання про вибір оптимального транспланта, що 
використовується для артросткопічної пластики ПХЗ стоїть і досі і вважається дискусійним. «Золотим стандартом» $\epsilon$ використання аутотрансплантатів 3 власних сухожиль пацієнта.

Більш новітньою та ефективною методикою є гібридна реконструкція ПХЗ 3 використанням штучного імпланта і аутоабо аллогенного сухожилля новітнього покоління, які рідко застосовуються в відділеннях травматології та ортопедії України, але вже стала доволі поширеною в закордонних клініках.

Інноваційна штучна зв'язка 3 плином часу проростає власною тканиною організму, стаючи новою власною зв'язкою, але при цьому не розтягується, оскільки має всередині штучний каркас. Спеціальна хірургічна техніка дозволяє гібридне поєднання живої тканини 3 штучним імплантом, поєднуючи переваги традиційних методів з штучної зв'язкою.

Але попри безліч сучасних матеріалів і типів протезів для ПХЗ ,має місце високий відсоток незадовільних функціональних результатів, ранніх та віддалених післяопераційних ускладнень, пов'язаних 3 імплантацією в суглоб синтетичних тканин. Тобто відбуваються розриви або перерозтягнення ПХЗ, як i у випадку 3 аутотрансплантами, а також реактивні синовії ти [11].

\section{III. МЕТА РОБОТИ}

Аналіз математичних моделей імплантатів для реконструкції травмованої передньої хрестоподібної зв'язки

\section{IV. МАТЕРІАЛИ ДОСЛІДЖЕННЯ}

Дослідження проводилось на даних статистики пацієнтів, отримані з відділення спортивної та балетної травми Інституту травматології та ортопедії НАМН України, зведених у таблиці 1 .

Таблиця 1 - Статистика травм пацієнтів відділення спортивної та балетної травми

\begin{tabular}{|l|c|}
\hline \multicolumn{1}{|c|}{ Тип хвороби } & $\begin{array}{c}\text { \% травмованих паціснтів за січень-квітень 2019 } \\
\text { року }\end{array}$ \\
\hline Перелами & 7 \\
\hline Вивихи & 2,9 \\
\hline Пошкодження м'язів & 3,9 \\
\hline Пошкодження сухожиль & 4,8 \\
\hline Пошкодження капсульно-зв'язувал. апарату & 11,8 \\
\hline Пошкодження менісків & 13,4 \\
\hline Пошкодження хрестоподібних зв'язок & 11,8 \\
\hline Пошкодження бокових зв'язок & 3,3 \\
\hline Бурсити & 2,9 \\
\hline Хвороби суглобів & 10,5 \\
\hline Хвороби кісток & 4,6 \\
\hline Хвороби хребта & 6,9 \\
\hline Хвороби м'язів & 2,8 \\
\hline Хвороби сухожиль & 3,2 \\
\hline Інше & 10,2 \\
\hline
\end{tabular}

Також використовувались МРТзнімки колінного суглоба пацієнтів 3 травмою ПХЗ та після проведення операції, довідникові дані механічних характеристик біологічних та штучних матеріалів, на основі яких було побудовано моделі ПХЗ у середовищі «SolidWorks»
Об'єктом дослідження є травми передньої хрестоподібної зв'язки, викликані спортивними травмами. Предмет дослідження - методи та імплантати для реконструкції травм ПХЗ.

Для вирішення задачі вибору
оптимального типу матеріалу для
реконструкції ПХЗ необхідно змоделювати 
в середовищі програми зв'язки, максимально надаючи їм властивості обраного матеріалу.

Для цього в «SolidWorks Simulation" необхідно прописати усі основні харак- теристики матеріалу для реконструкції ПХЗ. Так як це систематизовано у таблиці 2 на основі даних.

Таблиця 2 - Механічні властивості кісток та імплантів ПХЗ

\begin{tabular}{|c|c|c|c|c|}
\hline Властивість & Кістки & Аутотрансплантат ПХЗ & $\begin{array}{lr}\text { Синтетичний } & \text { трансплантат } \\
\text { ПХ3 } 3 \text { зполітетрафторетилену }\end{array}$ & Гвинт з триметиленкарбонату \\
\hline Модуль пружності, Н/м² & $10000 * 10^{3}$ & $20 * 10^{3}$ & $685^{*} 10^{3}$ & $4,2 * 10^{3}$ \\
\hline Коефіцієнт Пуасона & 0,3 & 0,3 & 0,5 & 0,3 \\
\hline Масова щільність, кг/м ${ }^{3}$ & 3030 & 1300 & 2200 & 1200 \\
\hline Межа пружності , H/м² & $128 * 10^{3}$ & $1 * 10^{3}$ & $14 * 10^{3}$ & $1,3^{*} 10^{3}$ \\
\hline
\end{tabular}

\section{V. РЕЗУЛЬТАТИ ТА ОБГОВОРЕННЯ}

Для визначення того, який вид трансплантатів для реконструкції травмованої передньої хрестоподібної зв'язки більш надійний, був проведений порівняльний аналіз математичних моделей аутотрансплантата і синтетичного імпланта в середовищі "SolidWorks Simulation" на основі механічних властивостей біологічних тканин людини та штучних імплантатів ПХ3, наведених в таблиці 2, створеної на основі довідникових даних $[4,5,11]$.

Для з'ясування міцності було умовно змодельовано центр колінного суглоба людини. Від внутрішньої поверхні латерального виростку стегнової кістки, до переднього міжщілинкового поля

великогомілкової кістки за допомогою біодеградованих гвинтів була закріплена ПХЗ. На змодельовану зв'язку діяли сили 3 сторони великогомілкової та стегнової кісток як на рис. 1.

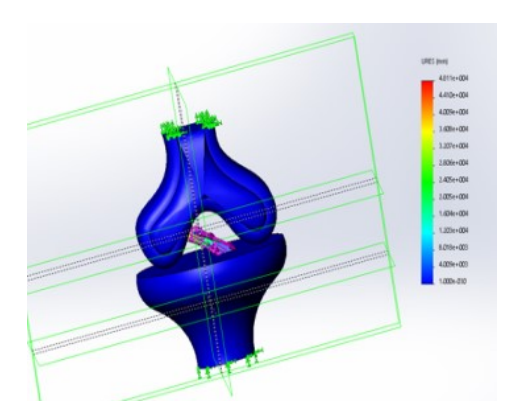

Рис.1 - Модель ПХ3

Метою експерименту був порівняльний аналіз механічних властивостей імплантатів ПХЗ, зроблених 3 різних типів матеріалу: аутотрансплантат ПХЗ та синтетичний трансплантат ПХЗ 3 політетрафторетилену. На ПХЗ подавалось навантаження і збільшувалось до моменту, доки зв'язка зовсім не порвалась, щоб визначити надійність зв'язки.

У середовищі була змодельована ПХЗ 3 тканин людини, прикріплена біорезробними гвинтами, виготовленими 3 D-полімолочної кислоти i триметилен карбонату. Даний аутотрансплантат ПХЗ розірвався при значеннях навантаження $203 \mathrm{H}$.

Наступним в точно те ж середовище умовно змодельованого колінного суглоба було поміщено синтетичний імплантат ПХЗ, виготовлений 3 біосумісного матеріалу політетрафторетилену. Під дією ідентичних зовнішніх чинників, що й на аутотрансплант, синтетична зв'язка порвалась при навантаженні $387 \mathrm{H}$.

Результати експериментального дослідження свідчать про те, що синтетичні зв'язки витримують більше навантаження в порівнянні ауто трансплантатом. Тому можуть бути використані для реконструкції ПХ3 у спортсменів, які матимуть постійні навантаження на колінний суглоб.

Підсумувавши та проаналізувавши все вище наведене, можна сказати, що на даному етапі розвитку медичних технологій, сучасним лікарям-травматологам варто більш часто розглядати реконструкцію ПХЗ методом мало інвазивної артроскопії 3 використанням синтетичних імплантатів. Тому що відповідно до отриманих даних саме такий підхід до лікування сприятиме скороченню часу реабілітації у спортсменів та допоможе їм в мінімальні терміни повернутись до занять. 


\section{VI. ВИСНОВКИ}

У роботі були проаналізовані основні аспекти травм та реконструкції передньої хрестоподібної зв'язки у спортсменів, оскільки дана категорія людей знаходиться в групі ризику повторного травмування. Тому особливий акцент ставився на тому, щоб визначити оптимальні методи реконструкції ПХ3, які 6 дозволяли спортсменам швидко повернутися до занять, при цьому уникаючи повторних травм даної ділянки колінного суглобу i деформації зв'язки.

$\begin{array}{crr}\text { В } & \text { результаті } & \text { проведеного } \\ \text { порівняльного } & \text { аналізу } & \text { математичних }\end{array}$
моделей аутотрансплантата і синтетичного імплантату виготовленого 3 політетрафторетилену в середовищі "SolidWorks Simulation" на основі механічних властивостей біологічних тканин людини та синтетичного імплантату ПХЗ, 3 використанням різних навантажень. Показано, що синтетична ПХЗ витримує навантаження до $387 \mathrm{H}$, в той час як зв'язка з тканин людини - лише $203 \mathrm{H}$.

Отже синтетичний імплантат 3 політетрафторетилену може бути використаний для реконструкції ПХЗ у спортсменів, які матимуть постійні навантаження на колінний суглоб.

\section{ПЕРЕЛІК ПОСИЛАНЬ}

[1] Geoffroy B. The Citius End: World Records Progression Announces the Completion of a Brief Ultra-Physiological Quest [Електронний ресурс] / B. Geoffroy, V. Thibault, M. Tafflet //https://doi.org/10.1371/journal.pone.0001552. - 2008. - Режим доступу до ресурсу: https://journals.plos.org/plosone/article?id=10.1371\%2Fjou rnal.pone. 0001552 .

[2] Сияк И. Мировые рекорды. Как изменились достижения атлетов за 100 лет [Электронный ресурс] / Иван Сияк // https://krastriathlon.ru. - 2016. - Режим доступу до ресурсу: https://krastriathlon.ru/news$18012016 /$

[3] Epidemiology of collegiate injuries for 15 sports summary and recommendations for injury prevention initiatives [Электронный ресурс] // http://www. Sportmedicine.ru/articles. - 2015. - Режим доступу до pecypcy:

http://www.sportmedicine.ru/articles/epidemiology_of_coll egiate_injuries.

[4] Сапин М. Анатомия и физиология человека / М. Сапин, В. Сивоглазов. - Москва: Academa, 2002. - 448 с. - (3). $-52 \mathrm{c}$.

[5] Головаха М. Л. Влияние сагиттального наклона плато большеберцовой кости на стабильность коленного сустава / Головаха М. Л., Красовский В. Л., Горелов А. М., Титарчук Р. В. // Ортопед., травматол. и протезирование. - 2012. - № 4. - С. 24-29

[6] Зазірний I. М. Фактори ризик у пошкодження передньої хрестоподібної зв'язки/ I. М. Зазірний. // Вісник ортопедії, травматології та протезування. - 2014. - №3. - C. 80-83.

[7] Paradowski J. Операция реконструкции передней крестообразной связки колена [Електронний ресурс] / JanParadowski // http://www.sport-med.pl. - 2016. Режим доступу до ресурсу: http://www.sportmed.pl/ru/операция-реконструкции-

acl\#Rekonstrukcja \%20więzadła $\% 20 \mathrm{i} \% 20$ leczenie.

[8] Розрив хрестоподібної зв'язки [Електронний ресурс] // https://arthroscopy.kiev.ua. - 2015. - Режим доступу до pecypcy: $\quad$ https://arthroscopy.kiev.ua/ua/розривхрестоподібної-звязки.html

[9] Ахпашев А. А. Функция коленного сустава во время ходьбы у больных с разрывом передней крестообразной связки коленного сустава до и после оперативного л / А. А. Ахпашев, Д. В. Скворцов. // Травматология и ортопедия России. - 2016. - №2. - С. $15-22$.

[10] Федорук Г. В. Современные технологии в эндопротезировании передней крестообразной связки коленного сустава / Г. В. Федорук, А. В. Голева. // Земский врач. - 2012. - №2. - С. 21-23.

[11] Русанов А. П. Фізична реабілітація хворих після реконструкції ПХЗ колінного суглоба при артроскопічних втручанннях / А. П. Русанов. - Київ, 2017. -223 c. 


\title{
МАТЕРИАЛЫ ДЛЯ РЕКОНСТРУКЦИИ ТРАВМИРОВАННОЙ ПЕРЕДНЕЙ КРЕСТООБРАЗНОЙ СВЯЗКИ У СПОРТСМЕНОВ
}

\author{
Лисичина С. В., студентка \\ redred1916@gmail.com \\ Беспалова Е. Я., доц,, к.б.н., с.н.с. \\ bespalova25.05@gmail.com \\ Кафедра БМИ, ФБМИ \\ Национальный технический университет Украины \\ «Киевский политехнический институт имени Игоря Сикорского» \\ Киев, Украина
}

\begin{abstract}
Реферат - В силу различных причин и особенностей в современном профессиональном спорте постоянно увеличиваются количество и тяжесть травм. Особенно важными и опасными являются повреждения нижней конечности, среди которых не последнее место занимают разрывы передней крестообразной связки, одной из самих травмированных связок коленного сустава.

Особенность травм ПХЗ у спортсменов заключается в том, что они после операчий долэны в максимально короткий срок вернуться к предыдущим тренировкам и выдерживать систематические нагрузки.

Классическая реконструкция передней крестообразной связки с использованием собственных тканей пациента и оперативным лечением сопутствующих повреждений не дает возможности быстро вернуться в профессиональный спорт, поскольку требует длительной релаксации и покоя до момента полного заживления раны.

Благодаря развитию биомедииинских технологий, одним из методов лечения разрыва ПХЗ стала малоинвазивная артроскопическая техника, которая обеспечивает более низкую травматичность вмешательства и ускоряет таким образом процесс реабилитации. Но несмотря на множество современных материалов и типов протезов для ПХЗ, имеет место высокий процент неудовлетворительных функциональных результатов, ранних и отдаленных послеоперационных осложнений, связанных с имплантацией в сустав синтетических тканей.

В работе был проведен сравнительный анализ методик реконструкиии травмирования передней крестообразной связки, определение недостатков в техниках и имплантатах, которые применяются сейчас, формирование основных требований для их совершенствования и разработка предложений особых требований для лечения спортсменов с травмами $\Pi X 3$

B cреде «SolidWorks» было условно смоделировано 2 образиа имплантатов связки, проведен математический анализ и сравнение синтетического имплантата и аутотрансплантата показывает, что синтетическая ПХЗ выдерживает нагрузку до 387 H, в то время как связка из тканей человека - лишь $203 \mathrm{H}$.

Учитывая все вымеуказанные данные, на данном этапе развития медицинских технологий, современным врачамтравматологам стоит более часто рассматривать реконструкиию ПХЗ методом малоинвазивной артроскопии с использованием синтетических имплантатов. Так как в соответствии с полученными результатами именно такой подход к лечению может способствовать сокращению времени реабилитации у спортсменов и поможет им в минимальные сроки вернуться к занятиям.
\end{abstract}

Ключевые слова - травмы коленного сустава, травма передней крестообразной связки, аутотрансплантат, синтетический имплантат, политетрафторэтилен. 


\title{
MATERIALS FOR RECONSTRUCTION OF INJURIES OFANTERIOR CRUCIATE LIGAMENT IN ATHLETES
}

\author{
Lysychyna Svitlana, student \\ redred1916@gmail.com \\ Bespalova Olena, Assoc. Ph.D. \\ bespalova25.05@gmail.com \\ Cathedra of Biomedical Engineering, FBMI \\ National Technical University of Ukraine \\ «Igor Sikorsky Kyiv Polytechnic Institute» \\ Kyiv, Ukraine
}

\begin{abstract}
Due to various reasons and peculiarities in modern professional sport, the number and severity of injuries are constantly increasing $s$. Especially important and dangerous are the injuries of the lower extremity, among which not the last place is occupied by the ruptures of the anterior cruciate ligament, one of the most injured ligaments of the knee joint.

The peculiarity of injuries of anterior cruciate ligament in athletes is that they, after operations, should return to previous workouts as soon as possible and withstand systematic loads.

Classical reconstruction of the anterior cruciate ligament using the patient's own tissues and the operative treatment of concomitant injuries does not allow for a quick return to professional sports, since it requires prolonged relaxation and rest until the wound is completely healed.

Due to the development of biomedical technologies, one of the methods for treating rupture of anterior cruciate ligament was the minimally invasive arthroscopic technique, which provides a lower invasiveness of the intervention and thus accelerates the rehabilitation process. But despite the many modern materials and types of prostheses for creating artificial anterior cruciate ligament, there is a high percentage of unsatisfactory functional results, early and late postoperative complications associated with the implantation of synthetic tissues into the joint.

During this research were carried out a comparative analysis of the techniques of reconstruction of the injured anterior cruciate ligament, identification of deficiencies in the techniques and implants that are used now, the formation of basic requirements for their improvement and the development of proposals for special requirements for the treatment of athletes with anterior cruciate ligament.

In the "SolidWorks" environment, 2 samples of communication implants were simulated conditionally. Mathematical analysis and comparison of a synthetic implant and an autograft shows that a synthetic anterior cruciate ligament can withstand a load of up to $387 \mathrm{~N}$, while a bundle of human tissues is only $203 \mathrm{~N}$.

Considering all the above data, at this stage of development of medical technologies, modern traumatologists should more often consider anterior cruciate ligament reconstructions using minimally invasive arthroscopy and synthetic implants. Since, in accordance with the results, such an approach to treatment can reduce the time of rehabilitation for athletes and help them return to work in the shortest time possible.
\end{abstract}

Key words: knee joint injury, anterior cruciate ligament injury, autograft, synthetic implant, polytetrafluoroethylene, 